\title{
Profiling Atheist World Views in Different Cultural Contexts: Developmental Trajectories and Accounts
}

\author{
Barbara Keller, Ramona Bullik, \\ and Constantin Klein \\ Bielefeld University
}

\author{
Sally B. Swanson \\ University of Tennessee at Chattanooga
}

\begin{abstract}
In the current study, we look at atheist or secular identities in different religious landscapes: In the U.S., the majority of the population indicates a belief in God. In West Germany, one third of the population reports no religious affiliation and a quarter identifies as "not religious," and in East Germany, most of the population explicitly identifies as atheist. Drawing on atheist worldview and identity literature from multiple disciplines, and using quantitative and qualitative data obtained in the U.S. and Germany during the "Bielefeld-based Cross-Cultural Study on the Semantics and Psychology of Spirituality," we examine self-identified atheists. First, self-identified atheist participants are portrayed quantitatively based on constructs expected to highlight differences between atheists and other "nones" and religious or spiritual persons: openness, a personality trait (NEO-FFI) documented to be higher in nonbelievers, positive relations, a dimension of eudaimonic well-being as indicator of social integration, generativity, concern for the welfare of future generations, and experiences of transcendence or "mysticism." Second, four case studies are presented that illustrate the wide range of distinct atheist beliefs, biographical experiences, and ideological positions by examining individuals' subjective definitions of "religion" and "spirituality" and personal interviews. The semistructured Faith Development Interview (FDI; Fowler, 1981) examines vertical and horizontal transcendence. By drawing on examples from our interviews, we show different descriptions of one's atheist worldview or "faith" in autobiographical remembering and reasoning. Thus, we work from a nomothetic toward an idiographic comparative perspective.
\end{abstract}

Keywords: atheism, cultural context, development, religion, secularization

Is the current religious landscape of Western industrialized countries characterized by "secularization"? How does this characterization impact narratives of atheist worldviews? Our review examines surveys which assess the degree of secularization in the United States and Germany, and empirical studies which portray self-identified atheist worldviews, and discussions of secularization as "grand" narrative of modernity. Secularization as a "grand" narrative is discussed differently in different cultural contexts. Depending on the view of religiosity as part of cultural and historical identity, the evaluation of secularization may emerge in different ways. Thus, we proceed from a quantitative and categor-

Barbara Keller, Ramona Bullik, and Constantin Klein, Department of Theology, Bielefeld University; Sally B. Swanson, Department of Psychology, University of Tennessee at Chattanooga.

Constantin Klein is now at Ludwig-Maximilian-Universität München, Germany.

This research was supported by the Deutsche Forschungsgemeinschaft (DFG, German Research Foundation) with Grant STR 570/15-1 to Heinz Streib.

Correspondence concerning this article should be addressed to Barbara Keller, Forschungsstelle Biographische Religionsforschung Fakultät für Geschichtswissenschaft, Philosophie und Theologie, Universität Bielefeld, Postfach 1001 31, D-33501 Bielefeld. E-mail: barbara.keller@unibielefeld.de ical approach across typologies and differentiated descriptions toward a narrative perspective on secularization. To understand the context in which narratives form, we examine the current religious landscape in both the U.S. and Germany.

\section{Changes in the Religious Field and Different Individual Trajectories}

In the U.S., the most recent estimates of the nonreligious population suggest that roughly $22 \%$ identify as unaffiliated or religious "nones" (Pew Research Center, 2015). Atheists make up 3\% of that population, making them the smallest subgroup of the religious "nones" below those who identify as agnostic (4\%) and those who identify as "nothing in particular" (15\%). However, according to recent data from the General Social Survey, only $7 \%$ of U.S. Americans identify as neither religious nor spiritual (Streib, Klein, \& Hood, 2016). Given that, according to the Religion Monitor survey from 2012 (Pickel, 2013), 57\% of U.S. Americans can be assumed to be "highly religious," and another $35 \%$ can be classified as "somewhat religious," the U.S. might legitimately be regarded as a religious country.

Although reunited 28 years ago, it is for a good reason still common in the sociology of religion to distinguish between East and West Germany (Froese \& Pfaff, 2005): In West Germany, the majority of the population (approx. 70\%) is still affiliated with a religious community, whereas most East Germans (approx. 75\%)

(C) American Psychological Association, 2018. This paper is hot the copy of record and may not exactly replicate the authoritative document published in the APA journal. Please do not copy or cite without author's permission. The final article is available, upon publication, at: http://dx.doi.org/10.1037/rel0000212 
have no affiliation to any religious tradition. These percentages are attributable, in particular, to the antireligious policy in the former German Democratic Republic, including the teaching of an atheistscientific worldview as doctrine in schools as well as oppression of churches and church members. In consequence, East Germans are on average less religious than West Germans. According to the data of the German general social survey, the ALLBUS, in 2012 $18 \%$ of the West Germans identified as neither religious nor spiritual, whereas more than half of the East Germans (54\%) described themselves neither as religious nor as spiritual (Streib, Klein et al., 2016). According to the Religion Monitor classification, $22 \%$ of the West Germans fall into the category as "highly religious" and 54\% as "religious." In East Germany, only $10 \%$ of the population belong to the group of "highly religious" and another 26\% to the group of the "religious" (Pickel, 2013). Whereas, according to the Religion Monitor survey 2012, 19\% of West Germans agreed either "fully" or "somewhat" to identify themselves as atheists, $44 \%$ of East Germans agree to describe themselves as atheists (Klein \& Streib, 2015). Clearly, regarding religious culture, East Germany appears to be much more strongly secularized than West Germany.

To summarize and put into a comparative perspective: the religious landscape of the U.S. is characterized by a high consent to self-identify as religious, by religious pluralism, and a wide variety of self-organized congregations. In Germany, the religious landscape is largely characterized by the Protestant and Catholic churches, which rely on the administrative support of the government, and subsequent on church taxes. Membership paying a church tax make up approximately two thirds of the population, with a rather small segment of "other" religious affiliations, leaving the last third of the population as nonaffiliated. In the "eurosecular" 1 West, not belonging or not believing is nothing "special." In the East, where during socialist times identifying as religious could be read as membership in a dissenting minority, not believing or not belonging is regarded as rather common. Being atheist may be seen and experienced differently in these distinctive contexts.

In the context of the U.S., the inclination to self-identify as "atheist" may be influenced by perceived prejudice against atheism. Gervais and Najle (2018) conclude atheism in the U.S. may be higher than stated in previous polls, reporting an estimate of $26 \%$ who identify as atheist when using an indirect measure of atheism. Earlier research by Gervais and an international team of researchers documents antiatheist prejudice worldwide, in varying degrees, even among atheists (Gervais et al., 2017). ${ }^{2}$ This suggests that prejudice may affect willingness to self-identify as atheist in different ways depending on the strength or pervasiveness of this prejudice.

Attitudes or characteristics previously related to atheist identity give us further insight into the role of what an atheist worldview may resemble. Focusing on "nones" or nonbelievers suggests a change of perspectives: to work toward understanding "atheists," and other "nones" not only according to what they reject but rather to what they believe or hold dear (Streib \& Klein, 2013). A pluralistic view is offered by Silver, Coleman, Hood, and Holcombe (2014) in the U.S., who employ qualitative grounded theory work to distinguish between six types of atheists: the academic, activist, seeker, antitheist, nontheist, and ritual atheist. Stolz (2017), working with a representative Swiss sample and mixed methods has presented a typology consisting of institutionals, alternatives, distanced, and secular, projected in a two-dimensional space organized by institutional religiosity and alternative spirituality (Stolz, 2017, p. 12). To achieve a more detailed picture of "secular identities," Schnell (2015) has used a theoretically and conceptually grounded dimensional approach for the assessment of atheism, agnosticism, scientism, personal responsibility, and humanism based on an Austrian sample. In her discussion of construct validity, she notes that there was no negative correlation between vertical self-transcendence (as Source of Meaning) and scientism. Would these typologies or configurations emerge in the same way in different cultural surrounds? Zuckerman, Galen, and Pasquale (2016) report, in their overview, differing relationships between religiousness and responses to personality measures in the U.S. compared with other parts of the world, such as Europe and, in particular, the United Kingdom (p. 118).

Working with an oral history approach, social historian Callum G. Brown presents an analysis of life narratives of atheists based on recent personal interviews in the United Kingdom, Canada, and the U.S., and material from archives in the respective countries. Brown observes: "Compared with most British researchers, American oral historians demonstrate a greater facility with religious issues, and a readiness to invite evidence of their respondents' religiosity." Brown further claims "the American cultural narrative visualizes religion within the overall life story," in contrast to Britain, where "religion becomes subordinate ... reduced to a question about Sundays 'in those days' rather than religion in the life" (Brown, 2017, p. 25). German cultural narratives are likely to be also influenced by "eurosecularity."

Although many scholars, in general, support the theory of secularization (Bruce, 2002, 2011; Dobbelaere, 2002; Martin, 2005; Pollack, 2003; Voas \& Chaves, 2016), others are more skeptical. Depending on certain contexts and foci of analyses scholars notice indicators of a persistence (Joas, 2005; Stark, 1999), "return of religion" (Graf, 2004; Hervieu-Léger, 1999), "spiritual turn" (Houtman \& Aupers, 2007), or even "spiritual revolution" (Heelas, Woodhead, Seel, Szerszynski, \& Trusting, 2005). Literary scholar Albrecht Koschorke (2013, p. 237) takes a different perspective and discusses secularization and the return of religion as two narratives of European modernity with the power to define reasons of conflict, to function as templates for the creation of solidarity or the drawing of boundaries (p. 258). Hidalgo assumes Koschorke's narrative approach and discusses secularization and the return of religiosity as seemingly opposite while narratively intertwined in different ways (Hidalgo, 2017, p. 25). Hidalgo sees this interplay as describing the "grand narratives" on secularization versus the return of the religious. However, some interplay of the "religious" and the "secular" may also characterize individual narratives and practices. For example, Smith (2017) has studied secular Sunday congregations in the U.S., asking how people who identify as secular seek 'collective 'religious' forms that imbue nontheistic

\footnotetext{
${ }^{1}$ Referring to higher numbers of nonreligious persons in most European countries. Discussed are, in comparison with the "religious" U.S., different church-state relations, religious pluralism and competition, and different ways to construct faith or religion and striving for knowledge in enlightenment narratives (cf. Berger, Davie, \& Fokas, 2008).

${ }^{2}$ In Europe, Czech Republic, Finland, and the United Kingdom were included. Germany was not part of this research.
} 
worldviews with special import through rituals that engage the emotional, moral, and personal" (p. 103). Based on survey data and biographical analyses in Germany and the U.S.A., Streib, Hood, and their research teams have studied privatized and individualized forms of religion. Adherents often label these as forms of "spirituality" and in some cases accept "atheist" selfidentifications (Streib \& Hood, 2016a; Streib et al., 2016; Keller, Streib, \& Hood, 2016).

In the current study, based on survey and interview data from Germany and the U.S., we portray self-identified atheists and nonreligious persons on central measures of religiosity, personality, and well-being to explore commonalities in general characteristics. Then we proceed to the idiographic presentation of four case studies, report their subjective definitions of "religion" and "spirituality," concepts used widely in everyday language as well as scientific discussion, however, with very different meanings and implications. Thus, we document different perspectives on the religious landscape to illustrate the nevertheless wide range of distinct atheist beliefs and ideological positions. Then we explore how respondents account for their being or becoming atheists in their interviews. We link quantitative psychometric characterizations, subjective understandings of concepts structuring varieties of being religious or spiritual, and interpretations of personal narrative to work toward understanding nonreligious world-views in their different contexts. Through these processes, we aim to provide a rich understanding of atheist and nonreligious views on their positions within their respective religious landscape.

\section{Method}

As part of the "Cross-Cultural Study of Spirituality," conducted in Bielefeld (Germany) and Chattanooga (U.S.A.), we examine data collected using a multimethod design, aiming at an in-depth understanding of what people call "spirituality." In a large sample in Germany and the U.S., self-report instruments such as psychometric scales, single items, and free entries of personal definitions of "spirituality" and "religion" are examined. Single-items asking for the participants' religious and spiritual identification and selfrating as well as for their identification as atheists or nontheists are included. The sampling procedure, aiming at capturing the varieties of being "spiritual," resulted in a sample of 1,113 participants in the U.S. and 773 in Germany. The instruments and data collection were approved by university IRB. The qualitative data consist of 102 rated Faith Development Interviews (FDI) with 54 persons from the U.S.A. and 48 from Germany who are portrayed here according to their self-identification as "spiritual," "religious," both, or neither, and as "theist," "atheist," or "nontheist."

First, we portray atheist study participants quantitatively. The personality trait openness to experience (a subscale of the NEOFFI; Borkenau \& Ostendorf, 1993; Costa \& McCrae, 1985; McCrae, Costa, del Pilar, Rolland, \& Parker, 1998) has been documented to be higher in nonbelievers. Eudamonic well-being is measured using the positive relations subscale, a dimension from Ryff's "Psychological Well-being and Growth" questionnaire (Ryff, 1989; Ryff \& Singer, 1998). We use positive relations as an indicator of social integration, which has been reported to be higher in religious persons (e.g., Galen \& Kloet, 2011) and is explored here to include nonreligious respondents. Additionally, we examine generativity, which is the concern for the welfare of future generations, measured by the Loyola Generativity Scale/ LGS (McAdams \& de St. Aubin, 1992; McAdams, de St. Aubin, \& Logan, 1993; McAdams, Diamond, de St. Aubin, \& Mansfield, 1997; McAdams, Hart, \& Maruna, 1998). Generativity relates differently to religion versus spirituality (Dillon, Wink, \& Fay, 2003) and is studied here using a design to include the nonreligious. Experiences of transcendence ("mysticism") are measured by the Mysticism Scale (M-Scale; Hood, 1975; Hood et al., 2001) as measure of the experiential core of religiosity or spirituality.

Based on the quantitative profile of a larger sample, we focus primarily on general characteristics of self-declared atheists and persons describing themselves as neither religious nor spiritual to illustrate what nonreligious groups might have in common crossculturally and across certain self-descriptions. Openness to experience is a core dimension of human personality defined as the disposition to embrace or reject novel ideas and experiences. Positive relations as assessed by Ryff (1989; Ryff \& Singer, 1998) describes the perception of an individual that $\mathrm{s} / \mathrm{he}$ has been able to maintain close, stable and trustworthy relationships with other people. Generativity (Erikson, 1951) can be characterized as an individual need to leaving a positive legacy for future generations and is measured with the LGS (McAdams \& de St. Aubin, 1992). Mysticism as operationalized in the M-Scale (Hood, 1975; Hood et al., 2001) includes the ineffable experience of a self-loss in greater unity, out of time and space ("introvertive mysticism"), feeling united with the multiplicity of all things which all appear to be somehow alive and connected ("extrovertive mysticism"), and a basic interpretation of such experiences as emotionally beneficial, noetic, and valuable ("interpretation"). A full description of all instruments can be found in Keller, Streib, Silver, Klein, and Hood (2016). The aforementioned scales measure constructs that atheists and other "nones" are expected to differ significantly from religious or spiritual persons. Atheists are expected to express somewhat higher openness to experience, less positive relations to others (Hunsberger \& Altemeyer, 2006; Streib \& Klein, 2013), and lower generativity (Dillon et al., 2003) than religious or spiritual persons. Additionally, atheists are very likely to report less mystical experiences of transcendence (Streib \& Hood, 2016b).

To broaden the perspective of atheist and nonreligious beliefs and positions and to illustrate how distinct such beliefs and positions can be depending on certain biographical backgrounds and experiences and broader cultural contexts, including the indication of participants regarded as outliers in their quantitative profiles, we turn to the findings of the interview responses. The FDI is a semistructured interview consisting of 25 questions covering four categories: (a) life review, (b) relationships, (c) current values and commitments, and (d) religion or worldview. The entire FDI and analysis methods are discussed in depth in Streib, Wollert, and Keller (2016) and in Keller, Coleman, and Silver (2016). In the current study, we use basic biographical information combined with accounts of becoming or being atheist, emphasizing the narratives that emerge from the interviews. Then we proceed to profiling single cases, linking profiles of central quantitative variables to subjective definitions of religion and spirituality, as indicators of how interviewees position themselves in their perceived religious landscapes. The profiles are then linked to the biographical narratives. However, before presenting our quantitative and qualitative results we start with a brief overview over some demographic characteristics of the sample which are detailed in 
Table 1. According to their self-identifications as religious and/or spiritual and as atheist or nontheist we have assigned the participants from both countries to three groups: (a) those who explicitly identified as atheists (in the following: "atheists"; $n=221$ ), (b) those who described themselves as neither religious nor spiritual, but did not explicitly identify as atheists ("not religious, not spiritual"; $n=201$ ), and (c) the remaining group of persons describing themselves as religious, spiritual, or both ("religious, spiritual, or both"; $n=1,464)$. Atheists as well as neither religious nor spiritual persons appear to be somewhat more likely to be male and better educated and less likely to be affiliated to any religious or spiritual group as compared with the religious and/or spiritual reference sample (see Table 1). Additionally, not religious and not spiritual respondents tend to be younger and have less economic capital. These distributions of demographic characteristics might reflect that, in general, disbelief in God is typically predicted by being younger, male, and more highly educated (Sherkat, 2008). In contrast, the demographic characteristics of individuals who display higher levels of religiosity might reflect, in general, elderly individuals (Hout \& Fischer, 2002) and women (Francis \& Penny, 2014; Klein, Keller, \& Traunmüller, 2017; Trzebiatowska, \& Bruce, 2012). Hence, in terms of demographic characteristics, our atheist and neither religious nor spiritual subsamples seem to represent both groups rather well.

\section{Profiling Implicit and Explicit Atheism Against "Nonatheism"}

First, we highlight profiles where the atheist and neither religious nor spiritual subsamples are displayed in comparison with the religious and/or spiritual reference sample regarding openness to experience, positive relations, generativity, and mysticism. Table 2 presents the results of a series of ANOVAs comparing the three subsamples across the two countries while controlling for effects of sex, age, and economic and cultural capital.

Effects of the demographic control variables, although sometimes significant, are generally low. While women report somewhat more positive relationships than men $(F=42.395 ; p<.001$; $\left.\eta^{2}=.022\right)$, higher educated persons tend to express more openness toward experiences $\left(F=44.343 ; p<.001 ; \eta^{2}=.023\right)$, and older persons are more likely to interpret mystical experiences as emotionally positive, noetic, and sacred $(F=44.004 ; p<.001$; $\left.\eta^{2}=.023\right)$. All remaining effects are smaller than $\eta^{2}=.020$. Similarly, the effects of the cross-cultural comparison between the U.S.A. and Germany are rather small. The only significant differences concern the degrees of openness to experiences (with the Germans expressing in general higher openness; $F=27.804 ; p<$ $.001 ; \eta^{2}=.015$ ) and generativity (with the Americans expressing generally higher generativity; $F=26.624 ; p<.001 ; \eta^{2}=.014$ ). The sizes of these effects remain on a rather low level. Most differences relate to the distinction between the three subsamples of atheists, neither religious nor spiritual persons and religious and/or spiritual participants. Both atheists and neither religious nor spiritual persons express higher openness to experience $(F=$ $20.318 ; p<.001)$, somewhat less positive relations $(F=10.211$; $p<.001)$, and lower generativity $(F=17.512 ; p<.001)$ as compared with the religious and/or spiritual subsample. While the effects for these differences are on a similar level as those previously reported $\left(.011<\eta^{2}<.021\right)$, the effects relating to the three subscales of the M-Scale are obviously stronger $\left(.128<\eta^{2}<\right.$ .233). Both atheists and neither religious nor spiritual persons score noticeably lower on both introvertive $(F=152.674 ; p<$ $.001)$ and extrovertive mystical experiences $(F=137.768 ; p<$ $.001)$ and the level of a meaningful interpretation of such experiences $(F=2284.697 ; p<.001)$. Hence, both atheists and neither religious nor spiritual persons self-report significantly fewer experiences of transcendence than religious and/or spiritual people while they appear to be somewhat more open to new ideas and experiences. In a social perspective, they perceive slightly less positive close relations to their family members and friends as compared with religious and/or spiritual persons and show somewhat lower interest in leaving a positive legacy for future generations. Interaction effects between country and subsample are, again, rather low, although some them are significant. The strongest interactions could be observed for extrovertive mysticism $\left(F=13.648 ; p<.001 ; \eta^{2}=.014\right)$ and for openness to experience $\left(F=9.894 ; p<.001 ; \eta^{2}=.010\right)$. In direct comparison, the effects of belonging to one of the subsamples atheists, neither religious nor spiritual, or religious or spiritual persons clearly make stronger differences over American or German nationality or interaction of both variables. Hence, although the cultural context has some impact on participant's quantitative profiles, positioning oneself as atheist or as neither religious nor spiritual in contrast to being religious and/or spiritual is of more importance concerning the selected behavioral dispositions.

In the "Cross-Cultural Study of Spirituality," the NEO-FFI subscale openness to experience and the M-Scale have been used to map the distribution of participants in a two-dimensional space by general openness toward new experiences in combination with a specific propensity toward the realm of the "spiritual" (Streib \& Hood, 2016b). The resulting quadrants of higher or lower openness and mystical experiences are used to identify cases that show high variability in their profiles which we select for a more comprehensive investigation with the FDI. In our current study, we apply the same algorithm aiming at different goals: (a) to illustrate the characteristic patterns of openness and mysticism of our atheist and neither religious nor spiritual subsamples in addition to the numbers presented in Table 2 and (b) to use the two-dimensional space to select respondents who appear to be rather representative for the groups of atheists and neither religious nor spiritual persons in terms of openness and mysticism for the case studies presented in the second part of this article. In Figure 1, the subsamples of atheists (white rhombs) and neither religious nor spiritual persons (dark gray circles) are plotted in the two-dimensional space of openness to experience and mysticism against the "background" of the reference sample of religious and/or spiritual participants (light gray circles). For standardization of the two axes, both openness to experience and mysticism sum scores are converted to $z$-scores.

The majority of atheists and neither religious nor spiritual respondents are located in the lower right quadrant, illustrating their lower levels of mystical experiences of transcendence and their higher levels of openness. From those atheists and neither religious nor spiritual participants who have been interviewed using the FDI, four cases have been chosen and studied for the second part of our study: Michael and Madeline from the U.S.A., Petra from East Germany, and Katja from West Germany. Although the cases appear to show expected characteristic profiles of openness and mysticism, the following paragraphs demonstrate a broad variety 


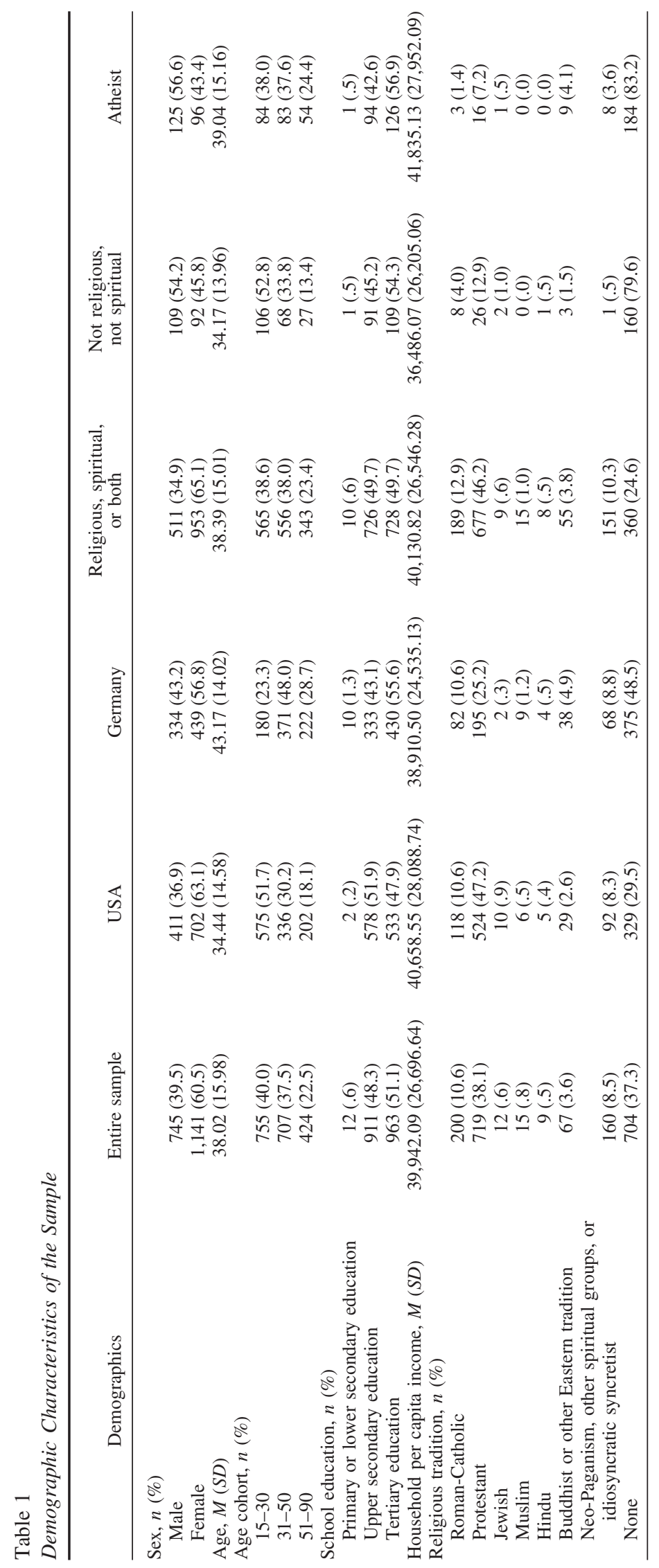


Table 2

Group Comparison of Target Variables (Openness, Positive Relations, LGS, M-Scale)

\begin{tabular}{|c|c|c|c|c|c|c|}
\hline \multirow[b]{2}{*}{ Dependent variable } & \multicolumn{2}{|c|}{$\begin{array}{l}\text { Religious, spiritual, } \\
\text { or both }\end{array}$} & \multicolumn{2}{|c|}{$\begin{array}{l}\text { Not religious and } \\
\text { not spiritual }\end{array}$} & \multicolumn{2}{|c|}{ Atheists } \\
\hline & USA & GER & USA & GER & USA & GER \\
\hline \multicolumn{7}{|l|}{ NEO-FFI - Openness } \\
\hline$M$ & 43.078 & 47.095 & 44.652 & 47.420 & 47.973 & 47.980 \\
\hline$S E$ & 0.209 & 0.273 & 0.610 & 0.646 & 0.642 & 0.557 \\
\hline \multicolumn{7}{|l|}{$95 \% \mathrm{CI}$} \\
\hline Lower limit & 42.669 & 46.560 & 43.457 & 46.153 & 46.714 & 46.888 \\
\hline Upper limit & 43.488 & 47.629 & 45.848 & 48.686 & 49.233 & 49.072 \\
\hline \multicolumn{7}{|c|}{ RYFF-Scale - Positive Relations } \\
\hline$M$ & 27.873 & 27.440 & 26.532 & 26.356 & 26.866 & 26.440 \\
\hline$S E$ & 0.144 & 0.188 & 0.421 & 0.446 & 0.444 & 0.385 \\
\hline \multicolumn{7}{|l|}{$95 \%$ CI } \\
\hline Lower limit & 27.590 & 27.071 & 25.706 & 25.481 & 25.995 & 25.686 \\
\hline Upper limit & 28.156 & 27.809 & 27.358 & 27.232 & 27.737 & 27.195 \\
\hline \multicolumn{7}{|l|}{ Loyola Generativity Scale } \\
\hline$M$ & 60.282 & 57.138 & 57.511 & 55.104 & 57.252 & 53.915 \\
\hline$S E$ & 0.279 & 0.365 & 0.815 & 0.864 & 0.859 & 0.745 \\
\hline \multicolumn{7}{|l|}{$95 \% \mathrm{CI}$} \\
\hline Lower limit & 59.734 & 56.423 & 55.912 & 53.410 & 55.567 & 52.454 \\
\hline Upper limit & 60.829 & 57.852 & 59.110 & 56.797 & 58.936 & 55.375 \\
\hline \multicolumn{7}{|c|}{ M-Scale - Introvertive Mysticism } \\
\hline$M$ & 42.819 & 46.182 & 32.454 & 33.717 & 34.689 & 32.727 \\
\hline$S E$ & 0.373 & 0.487 & 1.089 & 1.154 & 1.147 & 0.995 \\
\hline \multicolumn{7}{|l|}{$95 \%$ CI } \\
\hline Lower limit & 42.088 & 45.227 & 30.318 & 31.454 & 32.438 & 30.776 \\
\hline Upper limit & 43.550 & 47.137 & 34.591 & 35.980 & 36.939 & 34.679 \\
\hline \multicolumn{7}{|c|}{ M-Scale - Extrovertive Mysticism } \\
\hline$M$ & 27.136 & 30.050 & 21.494 & 20.125 & 22.144 & 19.935 \\
\hline$S E$ & 0.271 & 0.354 & 0.792 & 0.839 & 0.834 & 0.724 \\
\hline \multicolumn{7}{|l|}{$95 \%$ CI } \\
\hline Lower limit & 26.604 & 29.355 & 19.941 & 18.479 & 20.507 & 18.516 \\
\hline Upper limit & 27.667 & 30.744 & 23.048 & 21.770 & 23.780 & 21.354 \\
\hline \multicolumn{7}{|l|}{ M-Scale - Interpretation } \\
\hline$M$ & 47.478 & 47.897 & 36.932 & 35.375 & 36.059 & 33.718 \\
\hline$S E$ & 0.300 & 0.393 & 0.878 & 0.930 & 0.925 & 0.802 \\
\hline \multicolumn{7}{|l|}{$95 \% \mathrm{CI}$} \\
\hline Lower limit & 46.889 & 47.127 & 35.209 & 33.550 & 34.244 & 32.145 \\
\hline Upper limit & 48.068 & 48.667 & 38.655 & 37.200 & 37.874 & 35.292 \\
\hline
\end{tabular}

Note. Gender, cultural capital, average annual per-capita income, and age have been included as control variables.

in their orientations in the light of the qualitative data and certain outliers - or specific personal characteristics - in their quantitative profiles. In Table 2 we compare the three subgroups, and in the case studies we present individual profiles against the data of the corresponding subgroup to triangulate the case studies with the quantitative part of our study.

\section{Varieties of Atheism Close Up: Single Cases From the U.S.A and Germany}

The four case studies presented, two from the U.S. and two from Germany, are selected for further analyses not only because they represent the subsamples of atheists and neither religious nor spiritual persons well, but also due to the diverse positions toward religion and spirituality they capture. This is demonstrated first with participant's self-descriptions. ${ }^{3}$

In the U.S. sample, Michael chooses the identifier "neither religious nor spiritual" rather than identifying himself as atheist in the questionnaire. His low scores on the M-scale together with his comparatively lower scores in openness place him in the left lower quadrant of Figure 1. These findings of the questionnaire fit to his statements in the interview where he confesses to being a "closet atheist." Madeline, also from the U.S., moves away from the politically conservative and religious background of her family when reaching the age of 12 . She defines herself explicitly as atheist, and reports that she used to be quite outspoken regarding her views. This may be reflected in her higher scores on openness, which place her in the lower right quadrant.

\footnotetext{
${ }^{3}$ It is necessary to note here that their self-identifications as laid out in the interview can correspond to a greater or lesser extent to responses given in the questionnaire on which our calculations are based. Schwarz (1999) has explored how subjects use scales as source of information. Respondents do their best to be cooperative communicators, thus their answers represent their best choices according to their evaluation of the instrument and its supposed intentions. The interview offers more space for unfolding their own view or for commenting on questions.
} 


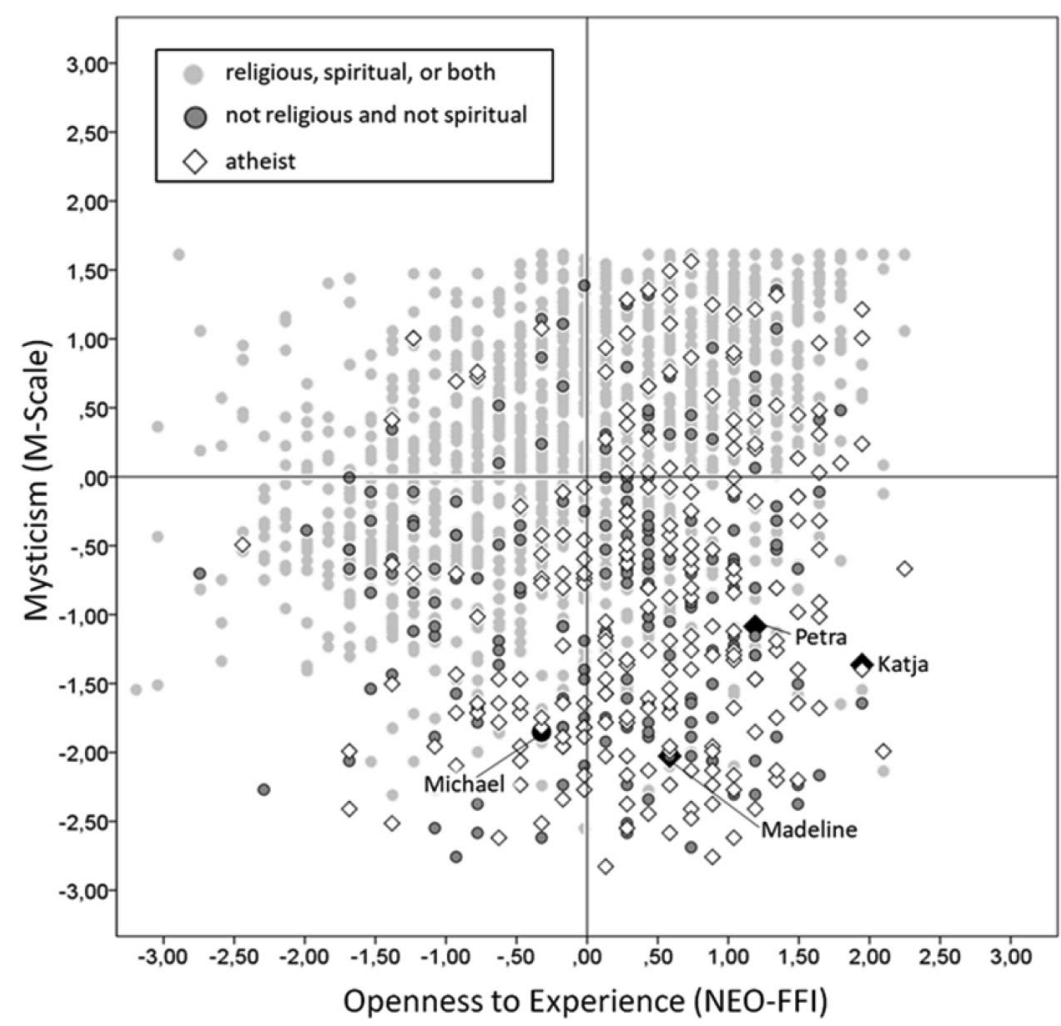

Figure 1. The interviewees and the three subsamples in the two-dimensional space of mysticism and openness to experience.

From the German sample we introduce Petra, a self-identified "more spiritual" atheist, who grew up in a religious environment in the a-religious former German Democratic Republic. The fourth case is Katja, a "neither religious nor spiritual" atheist who turned away from a "spiritual" environment, growing up in former West Germany. Similar to Madeline in the U.S., we find both German cases in the lower right quadrant, with Petra reporting a slightly higher score on the M-scale, signifying higher spirituality, and Katja displaying a slightly higher score on openness.

For each case, we provide some basic biographical information, report their definitions of "spirituality" and "religion," and compare their scores on the basic scales of openness, positive relations, generativity, and mysticism to those of the reference group. Then we link those profiles to the different biographies as told in the FDIs: How do they conceive of their position and how has their position developed in their biography?

\section{Michael and His Concerns to Reveal Atheism}

Michael is, at the time of the interview, a 24-year old American, ex-soldier, who deconverted from the Baptist tradition. He defines "spirituality" in the questionnaire as: "A belief in souls and spirits that is more loosely organized and group-oriented than religion. A spiritual person believes there are supernatural beings and forces which exist, but may not necessarily believe they are to be worshiped and revered." He defines "religion" as: "A belief in souls and spirits that is more organized and group-oriented than spirituality. A religious person believes both in supernatural beings/ forces, and that these beings should be worshiped and revered." $\mathrm{He}$ seems to draw a line between believing and not believing in supernatural beings, paralleling the distinction between knowledge and faith. Another line seems to be drawn between just believing that these beings exist and worshipping them, presumably in an organized way, which parallels the distinction between horizontal and vertical transcendence.

Michael in comparison with other American nonreligious and nonspiritual participants. Michael's score in openness lies below the lower limit of the confidence interval, whereas his score in positive relations lies above the upper limit. This score may mirror his efforts to protect his relationships and rather keep inner experiences to himself to avoid conflict with persons to whom he relates closely-topics he talks about in the interview. His scores on the M-Scale subscales are all below the lower limits of the confidence intervals which is not surprising for someone who self-identifies as neither religious nor spiritual. When we compare his score on openness to the mean of only the groups of atheists versus others, because of the higher scores of the German subsample (see Table 2), his position is more extreme, which may point to differences by country and cultural surround (see Table 3 ).

Michael's deconversion narrative. Michael tells a deconversion narrative which relates how he lost his faith (Table 4), following the structure identified by Labov and Waletzky (1967).

In his narrative, Michael first gives some orientation. He shows his familiarity with and reliance on a biblical text he holds dear, 
Table 3

Comparison of Michael With the Subsample of U.S. Nonreligious and Nonspiritual

\begin{tabular}{lcccc}
\hline \multicolumn{1}{c}{ Scale } & $\begin{array}{c}\text { Michael's } \\
\text { single score }\end{array}$ & Mean & SE & 95\% confidence interval \\
\hline Openness & 43 & 44.652 & 0.610 & {$[43.457,45.848]$} \\
Positive relations & 31 & 26.532 & 0.421 & {$[25.706,27.358]$} \\
Loyola Generativity Scale & 55 & 57.511 & 0.815 & {$[55.912,59.110]$} \\
M-Scale - Subscale Introvertive & 25 & 32.454 & 1.089 & {$[30.318,34.591]$} \\
M-Scale - Subscale Extrovertive & 8 & 21.494 & 0.792 & {$[19.941,23.048]$} \\
M-Scale - Subscale Interpretation & 27 & 36.932 & 0.878 & {$[35.209,38.655]$} \\
\hline
\end{tabular}

Judas' story. The complication arises when Michael discovers a version of the story of Judas which is different from the story that he knows and likes. When he tries to evaluate this experience, he seems at a loss. For the question, "How can I reconcile this?" he finds no answer and no resolution. The religious doubts he develops motivate his deconversion.

For further understanding, we examine the content of the story that Michael claims causes his doubts: In the version of the story as told in Acts, the one that Michael grew up with, Judas is bad and greedy, and God's punishment sets things right. In the other version of the story, according to Matthew, Judas regrets his betrayal and, as he cannot undo what he has done, kills himself. In the second story, Judas is a tragic figure, experiencing conflict, and it is more difficult to tell right from wrong. This may resonate with Michael's experience in combat. There, as he reports in the interview, the support of the chaplain helped him through a crisis, after he "had to shoot a kid," which may well indicate a traumatic experience and conflicts involving guilt. Perhaps Michael, who turned to intensive bible study upon his return to civilian life, expected some more reassurance. Instead, he found himself confronted with a story of conflict and remorse.

He talks about his deconversion as a slow process in the narrative cited above, explaining that his faith "just kind of went away" and this "happened slowly over a course of a couple of weeks." This contrasts with his labeling what happened to him while reading the Bible as a whole after he came back from the military, as a "massive fall that my Christianity took in 200x when I got back."

Impact on relationships. Throughout the explanation of his life story and where he currently finds meaning in life, he repeatedly cites the Christian faith of those around him, including his mother, his wife, a devout Christian friend, and his step-father, who is described as a "strong Christian" who initially inspired Michael to be a better Christian. Michael describes how his new identity, without a Christian faith, affects his relationships: His wife and friend know about his new atheist identity. His wife, whom he describes as "hardly a Christian," citing her lack of participation in prayer, reading the Bible, and attending church, is aware of his viewpoints, and even shares his disillusionment with religion. However, Michael says that when he speaks with her about inconsistencies in the bible, she chooses not to talk about it because she does not want a "crisis of faith." He describes the friend as an "honest Christian" with whom he likes to have conversations about religion. He says they share some viewpoints about the bible and religion and can confront differences with each other by leading honest discussions. His mother and step-father, however, are unaware of his change in faith. Michael explains that if his parents were to find out, they might dislike him or start to see him as a different person. For that reason, Michael explains that he considers himself "a bit of a closet atheist."

Michael explains his new-found identity as an atheist surrounded by Christian family: "Being atheist is like being sober in a car full of people that you think are drunk, and no one is pulling over to let you drive." He obviously feels different from those of his friends and family who are religious; he hopes that people would still accept him as the person he was and is, albeit without a religious belief.

How does the self-identified "closet atheist" from the U.S. conceive of something transcendent today? When asked about how his image of God or the divine changed, he states:

Maybe the closest thing that there is is just how amazing life is. You know? There is no mind creator of anything. I do not believe that there

Table 4

Michael's Deconversion Narrative: "I Never Really Found a Satisfactory Answer"

One of my favorite passages from when I was growing up is in Acts, where Judas is- after Jesus was killed, Judas is taking his money, Orientation and he goes and buys himself some land. God comes down on him and makes his chest explode. It always made me feel better, thinking that, you know, bad things may happen to me, but God has got my back. He is big, he is righteous, and he is going to be able to make things right in the end.

And, in Mathew, it tells a completely different story. In Mathew, Judas goes back to the priest; he is remorseful. He says, "This was horrible. This was a very bad idea. Why did I do this?" He throws the money back, he gives it back, tries to undo his mistake. And in his horrible utter grief, he goes and kills himself, because he cannot live with the decision he made.

That really, I guess you could say, was a shock to the system, because that is completely different from the story that I had been told when I was growing up. It just started to reveal the inaccuracies of the Bible in there. I starting asking, "How do we reconcile this?"

I never really found a satisfactory answer.

The more I kept reading about all this, the more I kept thinking: "You know what? I don't really think I believe this anymore." There was a real specific point where I am like, "You know what, I am an atheist; I don't believe this at all. This is bunk." But, it just kind of happened slowly over a course of a couple of weeks. That is pretty much the story.

Complication

Evaluation

Resolution

Coda 
is- at least not one that has revealed itself to us. I do not profess knowledge that there is no God. I do not find the evidence for it sufficient. That is the closest thing that I would view as being divine ... just the amazing complexity of life, everything, you know life has come up with, the universe itself.

Here, he displays a horizontal transcendence that is independent of "spiritual" semantics. He seems to have dismissed his faith for lack of evidence, taking an approach that sounds rather scientifically oriented (cf. the dimensions explored by Schnell, 2015). However, Michael also feels awe and wonder, which corresponds to findings on atheist types documented earlier in this line of work (cf. Coleman, Silver, \& Hood, 2016). Looking at him from the perspective of Silver et al.'s typology (2014), Michael may be categorized as a seeker-atheist: trying to keep the balance between religious, spiritual, and antitheist elements in his environment. Michael also displays a certain regret about not-believing anymore, a characteristic for this type of nonbeliever.

However, Michael also seems to struggle with deeper moral issues: When he was with the military, involved in fighting and killing, he had felt supported by the chaplain. Upon deployment from the armed forces and studying the bible he found himself not only not supported but shocked by the "horrible things" he found there. Instead of finding something good and reliable after his disturbing combat experiences, the comfort was revealed as an illusion. The image of the sober person among the drunks portrays Michael as lonely and perhaps even disenchanted with the atheist view he now identifies with and struggling with big questions: Is he still the same person? Are the criteria he relied on wellfounded? Perhaps privacy regarding his atheism points not only to awareness of prejudice (resonating with Gervais' observations) or striving to avoid conflict with the family but also to inner conflict and difficulties to come to terms with his perspective on what is good and what is reasonable? Then we might assume that he strives to protect the coherence of his social identity by keeping the potentially conflictual issue of his atheism out of family relationships. By sharing more individuative-reflective ideas with his friend, he may develop his atheist identity, although sheltered by the conventional identity shown toward his family.

\section{Madeline and Atheism as Scientific Perspective on Nature and Evolution}

Madeline, a 27-year-old American academic, defines "spirituality" in the questionnaire as "personal belief in a beyond-natural connection with other people or with nature." According to Madeline, "religion" refers to an "organization of people who agree on a simplistic explanation of the origins of ourselves and our surroundings." Madeline tells us that she deconverted from a "Christian" variety of religion. Her definitions accentuate a "scientific approach," an appreciation of the achievements of the Enlightenment, which successfully challenged religious creation stories. Religion is portrayed as intellectually restricting.

Madeline in comparison with other American atheists. In Table 5 we plot Madeline's scores against those of other selfidentified American atheists.

Madeline's scores on the subscales of the M-scale are much lower than those of her reference group-which may signify her uncompromising turn away from anything that might be deemed "religious" or her being "religiously unmusical,"4 not able to tune in to any religious experience. In comparison with other selfidentified atheists in Germany and the U.S. (see Table 2), Madeline is comparatively high on generativity.

Madeline's history of the development of her atheism-and of tolerance. Madeline looks back on how she developed her atheist stance: She gives a chronology of religious doubt in adolescence, defining herself as atheist, heated arguments with religious friends in high school, and, in her college years, efforts at understanding perspectives opposing her own.

Impact on relationships. Madeline remembers her earlier aggression with which she defended her atheist worldview. She seems unafraid of hurting relationships when voicing dissenting positions. As her ideas on how to handle religious conflict illustrate, she can envision disagreement as starting point of working toward universal goals:

Well, I think disagreement is not the end of a discussion, I think disagreement is really the beginning of a conversation about compromising one's needs just to set the universal goals and you know universal goals just become more and more apparent in the world as each might run out of resources or uhm I think that is number one.

Her concern with resources and universal goals corresponds to the high scores in generativity.

When rejecting "simplistic explanations of the origins," she seems to fight against constraints on thinking and for enlightenment, displaying a de-mythologizing view which resonates, to a certain extent, with Silver et al.'s (2014) description of the intellectual atheist. Madeline's account seems to follow the developmental line laid out by Fowler (1981): When she started to think critically, she applied criticism to the religion of her upbringing and found it less and less convincing-demarcating a typical move from synthetic-conventional to individuative-reflective faith and beyond, involving a deconversion. She seems to have trusted that her family would tolerate this step.

\section{Petra and Nontheist Spirituality as "Intellectual Honesty"5}

Petra, a 41-year-old German, according to the questionnaire "more spiritual" and nontheist, grew up in a religious environment in the former German Democratic Republic, where a materialist and atheist ideology prevailed. Her turn toward atheism occurred later, when the GDR was out of existence, along with any ban on religion associated with it. At the time of the interview, she supports humanist groups and groups critical of the church, she strives to avoid harming others, and she thinks that religion should be a private matter. In the survey she describes what "spirituality" means to her: "to confront oneself with existential questions, contemplation, to trace one's feelings, to want to experience concepts like 'infinity,' 'transcendence,' to want to move beyond the mundane, to learn how to live the 'right,' 'good' life, to solve

\footnotetext{
${ }^{4}$ This expression was used by Max Weber in his letter to Ferdinand Tönnies on Sept. 2, 1909 (Weber, 1994).

${ }^{5}$ Petra may be alluding to the position taken by German philosopher Thomas Metzinger, who discusses spirituality as epistemic attitude, aiming at experience-based knowledge involving self-knowledge, inner awareness, and striving toward ethical integrity (Metzinger, 2013).
} 
Table 5

Comparison of Madeline With Subsample of U.S. Atheists

\begin{tabular}{lcccc}
\hline \multicolumn{1}{c}{ Scale } & $\begin{array}{c}\text { Madeline's } \\
\text { single score }\end{array}$ & Mean & SE & 95\% confidence interval \\
\hline Openness & 49 & 47.973 & 0.642 & {$[46.714,49.233]$} \\
Positive relations & 27 & 26.866 & 0.444 & {$[25.995,27.737]$} \\
Loyola Generativity Scale & 58 & 57.252 & 0.859 & {$[55.567,58.936]$} \\
M-Scale - Subscale Introvertive & 18 & 34.689 & 1.147 & {$[32.438,36.939]$} \\
M-Scale - Subscale Extrovertive & 10 & 22.144 & 0.834 & {$[20.507,23.780]$} \\
M-Scale - Subscale Interpretation & 28 & 36.059 & 0.925 & {$[34.244,37.874]$} \\
\hline
\end{tabular}

moral problems." "Religion" is, in her view: "Superstition, storyteller, models for the explanation of the world, manmade, moral guide without legitimation, contradictions."

In her view on religion we can see, again, scientific reasoning, perhaps some heritage of a discussion linked to an agenda of the Enlightenment, and demands to do without manmade illusions and false certainties. Her definition of spirituality reveals the attitude of a seeker who dares to confront herself with existential questions. Thus, her efforts at soul-searching, which in her view characterizes her atheist spirituality and is linked to religion, might be seen as an example of a German version of the seeker-agnostic in Silver et al.'s typology (2014). Like Michael from the U.S., she seems to be constantly looking for the "scientifically wondrous" (Silver et al., 2014, p. 994).

In her interview, Petra elaborates on her view on spirituality as follows:

Well, to listen to yourself, because this is what religion, I believe, has prescribed, that you search yourself to suddenly hear truths ... but I have to be radically honest to myself, and this can be unpleasant. ... Spirituality does not have to be wellness ... and it does not mean that when I discard religion, that then I feel well or everything is fine. But I am glad to be able to see the good Lord from a distance. It seems to fade away, and is without meaning, almost.

Petra in comparison with other German atheists. In Table 6 we plot Petra's scores against those of other German selfidentified atheists.

Petra's scores in positive relations and generativity are lower than the means of her reference group while her score in openness turns out to be higher than average. The score for the subscale interpretation of the M-scale is clearly lower, whereas those for introvertive and extrovertive correspond to those of the reference group. This may underline her rejection of religious understanding of transcendent experience. The low scores on generativity, considering that the scores of the German subsample are lower in comparison with the
American, and on positive relations to others, may correspond to her interview, which consists of extensive considerations with sparse references to her personal life. However, there is a narrative, and the narrative is about becoming an atheist.

Petra's narrative of becoming an atheist. In the interview, Petra elaborates on her quest, demanding that one has to be "radically honest," even if this involves emotional distress (see Table 7).

According to Labov and Waletzky, we can identify these characteristics of a narrative: The orientation gives as starting point her childhood religiosity, which was not questioned. The complication arises when a friend sets out to study theology and Petra seeks to understand what her friend is studying. According to her evaluation, her research undermines the relationship with her friend and also affects her studies in theology. Petra developed, as a resolution, an attitude of relying on continuous research, which results in her identifying herself as atheist (coda). In this personal "enlightenment narrative," religion is evaluated negatively.

Impact on relationships. The narrative about studying theology and leaving religion is also a narrative about the breakup of the relationship with her friend. Petra seems to regard this as a sad, but inevitable consequence of her search for intellectual honesty. For her, this does not mean self-identifying as an intellectual, "but simply to ask questions, such as: am I staying with myself here? Is this exactly what I understand that it is?"

Petra's "faith biography" spans from growing up as a "child of divorce" in a Christian environment in the predominantly atheist GDR to living as atheist in contemporary Germany, where the larger part of the population belongs to one of the two integrated churches, is therefore Protestant or Catholic. Identifying as a "spiritual atheist" gives her biography coherence, even leaving room for some ambivalence toward the God in whom she does not believe anymore: She can keep the inner experience but can do

Table 6

Comparison of Petra With Subsample of German Atheists

\begin{tabular}{lcccc}
\hline \multicolumn{1}{c}{ Scale } & $\begin{array}{c}\text { Petra's } \\
\text { single score }\end{array}$ & Mean & $S E$ & 95\% confidence interval \\
\hline Openness & 53 & 47.980 & 0.557 & {$[46.888,49.072]$} \\
Positive relations & 24 & 26.440 & 0.385 & {$[25.686,27.195]$} \\
Loyola Generativity Scale & 50 & 53.915 & 0.745 & {$[52.454,55.375]$} \\
M-Scale - Subscale Introvertive & 33 & 32.727 & 0.995 & {$[30.776,34.679]$} \\
M-Scale - Subscale Extrovertive & 20 & 19.935 & 0.724 & {$[18.516,21.354]$} \\
M-Scale - Subscale Interpretation & 29 & 33.718 & 0.802 & {$[32.145,35.292]$} \\
\hline
\end{tabular}


Table 7

Petra's Narrative of Becoming an Atheist: "I Started to Do Research ..."

I was told these things when I was a child and I took it really seriously and I have always prayed for good things etc. but, really, I did not have any conflict until

[...] a friend of mine suddenly turned to theology, wanted to study theology, and so I engaged myself with this as well and in hindsight I think I did that because I cared about him and because I could not understand why he would do that ... and then I started to do research and to deal with this .... and then, naturally, my awakening set in, so to speak, I rationally pondered about it, and listened to myself and tried to define this word „God“" for me, for the first time, what is this, what is meant by this, how do others understand this etc. and I have really deeply immersed myself in that

and this led finally to a break-up with this person und he did, of course, not become a theologian today

and so I finally developed my attitude, refining and changing it over the years, always reading and hearing new things,

and I, well, I would call myself atheist.

Orientation

Complication

Evaluation

Resolution Coda without God. Being not just atheist, but also "spiritual" keeps her story compatible with other "spiritual" discourses in the larger society.

\section{Katja and Her Concern With the Preservation of the Planet}

Katja is a 35-year-old German professional, neither religious nor spiritual and atheist. Her definition of the term "spirituality" as stated in the survey is: "Beliefs which cannot be corroborated by science, including premonition or the interpretation of dreams. Everything which is esoteric."

On "religion" she writes: "Mythology. The attempt to explain things which (yet) cannot be explained by science. Power and control by fear and awe toward higher power." Interestingly, the term "belief" is only used for "spirituality," not for "religion." For her, "religion" is associated with claims to higher knowledge and manipulation by a frightening higher power. This association indicates vertical transcendence, in this case implying a malicious otherworldly power. "Spirituality," on the other hand, is instead defined by private beliefs or practices, horizontal transcendence, implying something irrational, but probably harmless. Her critical stance toward religion, which is not only based on a scientific perspective but also on the accentuation of dangerous aspects of religion, may qualify her as an example of a German version of Silver et al.'s (2014) antitheist. She seems to have maintained at least some of that missionary zeal from her youth, emphasizing the downsides of religion and on the importance of engaging for humanity and the environment in a secular manner.

Katja in comparison with other German atheists. Katja shows, compared with other German atheist persons in our sample, higher scores on openness to experience, positive relations, and generativity. The latter is interesting, as it would still be high compared with the American subsample, which has higher means in generativity than the German subsample (see Table 8).

Her scores for introvertive mysticism and religious interpretation from the M-scale are lower in comparison. However, her score for extrovertive mysticism is higher than that of her reference group. For a better understanding of this profile, we turn to her interview.

Katja's narrative on her confrontation with theodicy. In Table 9 we present Katja's narrative on how she is dealing with the question of an unjust God.

Katja describes, in the orientation of her narrative, her teenage ideology which focused on the protection of environment and animals. The engagement with these topics involved realizing that there is a lot of suffering and injustice. This led her to the view that she could not believe that there was a good and almighty God. As an evaluation of her struggle with the challenge of theodicy, she states that this realization even enhanced her appreciation of life, made it seem more precious to her. Her resolution then is that this precious life has to be protected and valued. She explicitly cautions against leaving this to some higher power, instead her focus is on herself and the responsibility she can take herself. This shows her deeply involved with something that transcends everyday life, which we may call an ultimate concern. We may read Katja's narrative as portraying the development of horizontal transcendence. Above, we noted that extrovertive mysticism is framed by unity and inner subjectivity, implying an outward merging with the wholeness of all existence. Thus, her atheist stance goes along with her high extrovertive mysticism.

Impact on relationships. When asked about breakthrough experiences, Katja states that her turn away from religion could be described as a kind of liberation, because in her early childhood religion was associated with fear and pressure. Freeing herself

Table 8

Katja in Comparison With Subsample of German Atheists

\begin{tabular}{lcccc}
\hline \multicolumn{1}{c}{ Scale } & $\begin{array}{c}\text { Katja's } \\
\text { single score }\end{array}$ & Mean & SE & 95\% confidence interval \\
\hline Openness & 58 & 47.980 & 0.557 & {$[46.888,49.072]$} \\
Positive relations & 34 & 26.440 & 0.385 & {$[25.686,27.195]$} \\
Loyola Generativity Scale & 64 & 53.915 & 0.745 & {$[52.454,55.375]$} \\
M-Scale - Subscale Introvertive & 25 & 32.727 & 0.995 & {$[30.776,34.679]$} \\
M-Scale - Subscale Extrovertive & 22 & 19.935 & 0.724 & {$[18.516,21.354]$} \\
M-Scale - Subscale Interpretation & 27 & 33.718 & 0.802 & {$[32.145,35.292]$} \\
\hline
\end{tabular}


Table 9

Katja's Narrative on the Challenge of Theodicy: "I Do What I Can, Now and Here, to Make This World a Better Place"

I was going through an idealistic period in school, environmental issues, protection of the environment, animal protection, protection of human life and all that

[...] and I thought, as teenager, quite radically, if God is really almighty, he must be an asshole, sounds silly, but then I would not pray to him,. . .but I'd rather believe there is no God, because then I would not have to accuse him, but in my head the likelihood that there is something dwindled down.

And this enhanced, for me personally, the beauty of life, life just turned more precious. Supposing that there is nothing after life, life is, for every human being, animal or whatever, the only thing we have.

[...] therefore it has to be protected, it has to be lived in a positive, a true way, and one has to respect the lives of others, and let them live, and this responsibility, ... to take responsibility and not shift it to some higher power,

But to say, I do what I can, now and here, to make this world a better place.

Orientation

Complication

Evaluation

Resolution

Coda from this belief made her feel good. Other than that, she does not name any significant changes in relationships that went along with her turn to atheism. Katja is concerned with the well-being of others which corresponds to her high scores in positive relations. She wants to leave her children a healthy planet, which goes along with her high scores on generativity. She sees organized religion as dangerous to human relationships:

And then later it became apparent how religion divides, how religion sets apart instead of bringing together. How people fight each other, if they really think they are backed by a superpowerful being. . . . I mean, there are wars without religion, ... but then, perhaps, it is not so easy to find adherents who are willing to risk their lives; [on the other hand it is probably easier] if you can tell that life is only a short episode after which you go to heaven to get your reward. There I really see danger with religion, less with spirituality, which is a personal thing for everybody to dream and think.

For Katja, the promises of an afterlife (and being rewarded therein) may seduce people to go to war and sacrifice their lives, and she blames organized religion for that.

\section{Atheisms in Different Social and Cultural Surrounds}

The quantitative cross-country comparison shows differences concerning openness, which is higher in the German subsample, and generativity, which is higher in the American sample. To understand the role of these differences we highlight material in the individual profiles:

The single cases show some differences when looking at their psychometric profiles. We noted comparatively low openness for Michael, which we understand to be in connection with his identifying as a "closet atheist," a self-description not yet found in German data. Madeline showed low scores on all subscales of the M-scale, which may portray her as "religiously unmusical." Petra's profile is characterized by an extremely low score on the subscale interpretation of the M-scale, which may show her turn away from belief systems and toward her quest. We found comparatively high extrovertive mysticism and, even if compared with the higher scores of the American sample, high generativity for Katja, who shows a deep concern for the preservation of the planet.

Next, we took a comparative perspective on the different "atheist" positions gained from the interviews. Starting with the respondents from the U.S., Michael seems to deal with some conflicts regarding his previous faith, being unable to tell some of his family, and even cites specific instances in reading the bible that impressed him as negative and contributed to leaving his faith.
Madeline notes her ambivalence toward religion, which developed toward outspoken atheism first and to a more tolerant position recently. Although the cases in some points show contrasting experiences, both individuals were raised in religious homes, and ultimately chose to leave religion for a type of nonbelief. Michael's case highlights conflicts individuals may feel as a minority group (atheists) in the U.S. Madeline exposes an ambiguity toward religion where viewpoints are flexible and can be incorporated into a broader landscape of diverse worldviews.

Michael frames most of his answers around the notion that he is no longer religious while the rest of his family still is; Madeline, on the other hand, refers to religion less in her interview expressing that, in contrast to Michael, religion is not something she thinks about anymore. For her, religion is "on the backburner," whereas for Michael religion still seems to be an important aspect of his life, even if he has rejected Christianity.

For Petra, who grew up in a religious minority in the former GDR, her quest has involved the break-up of an important friendship. Although she feels sad about this loss, she makes it clear that it is important to her to be honest. However, it seems that the conflict was more about disagreeing with her friend's views and less about the label "atheist." Petra seems to put her striving toward intellectual honesty first, even if it may involve putting relationships at risk.

Katja, who is concerned with environmental issues and destructive human behavior like war, sees "religion" as something that is likely to keep people apart or even set groups of people against each other. Like Madeline, she holds a scientific world view, however without mentioning big conflicts or quarrels about being an atheist.

Research suggests that atheists in the U.S. represent a marginalized social group. Prejudice is stronger toward atheists than any other religiously affiliated group (Edgell, Gerteis, \& Hartmann, 2006). Gervais and Najle (2018) documented underreporting of atheist identities likely due to antiatheist prejudice in the U.S. This may resonate with Michael's decision to keep his atheism to himself. For Madeline, in contrast, discussion of differing views could be a way toward universal goals and cooperation. Michael seems to take a cautious or defensive position regarding his atheism, which he reveals in relationships where he feels safe to do so. Madeline has been offensively putting her atheism forward in her younger years and now takes care not to offend persons with differing worldviews.

The German interviewees have different biographical and social backgrounds. Petra belonged to a minority deviating from the 
atheist mainstream culture when she grew up in a religious environment in the former GDR. Katja grew up in former West Germany, Protestant, feeling free to articulate her doubts. Both German respondents do not articulate needs to hide or defend their atheist notions in their families or toward other persons in general as much as the two U.S. cases we described, neither do they discuss the problem of offending religious persons by putting forward their atheist positions. It seems to be more usual, for them to voice nonbelief, which may resonate with higher openness in the German subsample. Thus, participants' narratives support the coherence of their biographies and provide space to negotiate the compatibility of their respective biography with their current view of the surrounding larger society.

\section{Discussion}

We have drawn on literature from different disciplines and from different "cultural surrounds" to discuss secularization versus return of religion as phenomena reported based on answers in surveys and on biographical narratives. In the empirical work presented here, we strived to illustrate and explore the biographical background of the development of atheist worldviews in four case studies. In a nutshell, we can underline that there is more than one way of being atheist. We find different routes to become an atheist, but also very different ways of understanding as and presenting (or not presenting) as one. What all our cases have in common is some kind of conflict with religion as it was presented to them. This results in a turn away from religion, but while Madeline and Katja have completely forsaken religion and/or spirituality, for Michael and Petra their pursuit may not yet be over. They still seem to seek answers, perhaps from religion or from the engagement in some form of spirituality, which may go along with identifying as atheist. This may also show "atheisms" can coexist with "spiritual" or even "religious" notions in personal "faith."

\section{Limitations}

The interdisciplinary and cross-cultural literature review is illustrative of joining different perspectives rather than exhaustive. Empirical work presented here is based on a segment of a larger research sample, profiling atheists from East and West Germany and the U.S. against "nones" and "religious, spiritual or both," first relying on quantitative comparisons of well-founded, however culturally situated, psychometric instruments, then focusing on single atheist cases. Although we could highlight some differences documented in the quantitative data, such as higher openness in the German subsample, the difference in generativity may deserve exploration in future research. The cases presented and discussed cannot claim representativity. They have been taken from a sample of people who may have varied in their motivation to be interviewed on questions of faith. In East Germany, this may be a more "special" inclination than in the U.S., because being religious is much less common there and questions around being religious or not are unlikely to be major concerns. Nor can the cases presented form another typology of being atheist. Rather, the cases exemplify options for attending to culturally sensitive interpretations of cross-cultural work with different types of data and taken from different research sites and perspectives.

\section{Suggestions for Future Research}

For the further exploration of atheism, we offer these suggestions:

Looking beyond the binary. Our current observation that atheism can coexist with religious or spiritual notions, which is in line with earlier research (Coleman et al., 2016; Keller et al., 2016) and can be taken together with Schnell's (2015) observation that vertical transcendence can go along with scientism. We noted the challenge to place a person in one category of a given typology of being atheist. It might be worthwhile to keep a wider lens on different dimensions of individual appropriations of secular and religious notions and work beyond focusing on a binary of "secular" versus "religious" world views. Also, it might be worthwhile to study, along with the semantics of "spirituality," the semantics of "religion" as applied and understood in subjective selfidentifications.

Cross-cultural mixed method designs and interdisciplinary discussion. Future research should explore the semantics of "atheist," "religious," "spiritual," or other labels used as selfidentifications as well as structuring perceptions of one's surrounding religious landscape, from a cross-cultural perspective. These labels may characterize the various perceived social surrounds of atheist worldview development, which may be experienced and evaluated differently dependent on the surrounding. This in turn may impact reporting one's identification as well as communicating it in one's personal life and relationships. Crosscultural designs including "social-geographical semantics" and narrative methods allow to decipher different negotiations of what may be deemed religious, atheist, or else.

Further pursuit of multimethod strategies for the portrayal of varieties of atheist world views, to attend to quantitative and qualitative results, teasing out correspondences as well as tensions, should be considered in future research. Also, drawing on oral history, literary criticism and related disciplines exploring accounts on religiosity, spirituality or secularity in different cultural contexts and traditions may help to locate individual biographical narrating and reasoning in relation to specific cultural narratives, or, vice versa, to trace cultural models in individual narratives. The combination of nomothetic or top-down and idiographic or bottom up methods in cross-cultural perspective promises a reflective perspective on general categories informed by refined (local) descriptions.

Longitudinal perspective. From a developmental perspective we argue for longitudinal designs, which allow observation by following changes in development as observed and changes in development as narrated by respondents in their different, also changing, environments. It may be enlightening to see whether atheist or other identifications stay stable or change, and how narratives accounting for these identities change when retold a couple of years later, from a different phase in one's life. If changes in the narrative occur, can they be linked to changed personal circumstances? Or even to a societal change? Additionally, adding historical to social geographical semantics: how are changes in the religious landscape referred to, negotiated, or bypassed in individual narratives, can we trace "cultural narratives" in changing individual reviews? These and other questions need to be pursued further to understand how atheisms are seen and how atheists identify and see themselves. Combining the cross-cultural 
and longitudinal perspective, future research might put a stronger focus on international and interreligious discussion and reflection of methods and concepts and their histories in different cultural traditions.

\section{References}

Berger, P., Davie, G., \& Fokas, E. (2008). Religious America, secular Europe? A theme and variations. New York, NY: Taylor \& Francis.

Borkenau, P., \& Ostendorf, F. (1993). NEO-Fünf-Faktoren-Inventar (NEO-FFI) nach Costa und McCrae: Handanweisung. Göttingen, Germany: Hogrefe, Verlag für Psychologie. [NEO-Five Factor Inventory (NEO-FFI) according to Costa \& McCrae: Manual].

Brown, C. G. (2017). Becoming atheist. Humanism and the secular West. London, UK: Bloomsbury.

Bruce, S. (2002). God is dead. Secularization in the West. Oxford, UK: Oxford University Press.

Bruce, S. (2011). Secularization: In defense of an unfashionable theory. Oxford, UK: Oxford University Press. http://dx.doi.org/10.1093/acprof: osobl/9780199654123.001.0001

Coleman, T. J., Silver, C. F., \& Hood, R. W. (2016). “. . . if the universe is beautiful, we're part of that beauty." A "neither religious nor spiritual" biography as horizontal transcendence. In H. Streib \& R. W. Hood (Eds.), Semantics and psychology of spirituality: A cross-cultural analysis (pp. 355-372). Cham, Switzerland: Springer.

Costa, P. T., \& McCrae, R. R. (1985). Revised NEO Personality Inventory (NEO PI-R) and NEO Five-Factor-Inventory (NEO-FFI): Professional manual. Odessa, FL: Psychological Assessment Resources.

Dillon, M., Wink, P., \& Fay, K. (2003). Is spirituality detrimental to generativity? Journal for the Scientific Study of Religion, 42, 427-442. http://dx.doi.org/10.1111/1468-5906.00192

Dobbelaere, K. (2002). Secularization: An analysis at three levels. Brussels, Belgium: Lang.

Edgell, P., Gerteis, J., \& Hartmann, D. (2006). Atheists as "other": Moral boundaries and cultural membership in American society. American Sociological Review, 71, 211-234. http://dx.doi.org/10.1177/ 000312240607100203

Erikson, E. (1951). Childhood and society. New York, NY: Norton.

Fowler, J. W. (1981). Stages of faith. San Francisco, CA: Harper \& Row.

Francis, L. J., \& Penny, G. (2014). Gender differences in religion. In V. Saroglou (Ed.), Religion, personality, and social behavior (pp. 313337). New York, NY: Psychology Press.

Froese, P., \& Pfaff, S. (2005). Explaining a religious anomaly: A historical analysis of secularization in Eastern Germany. Journal for the Scientific Study of Religion, 44, 397-422. http://dx.doi.org/10.1111/j.1468-5906 .2005.00294.x

Galen, L. W., \& Kloet, J. (2011). Personality and social integration factors distinguishing nonreligious from religious groups: The importance of controlling for attendance and demographics. Archiv für Religionspsychologie / Archive for the Psychology of Religions, 33, 205-228. http:// dx.doi.org/10.1163/157361211X570047

Gervais, W. M., \& Najle, M. B. (2018). How many atheists are there? Social Psychological \& Personality Science, 9, 3-10. http://dx.doi.org/ 10.1177/1948550617707015

Gervais, W. M., Xygalatas, D., McKay, R. T., van Elk, M., Buchtel, E. E., Aveyard, M., . . . Bulbulia, J. (2017, August 2). Global evidence of extreme intuitive moral prejudice against atheists. PsyArXiv. Retrieved from psyarxiv.com/csnp2. http://dx.doi.org/10.17605/OSF.IO/CSNP2

Graf, F. W. (2004). Die Wiederkehr der Götter: Religion in der modernen Kultur [The return of the gods: Religion in modern culture]. München, Germany: C. H. Beck.

Heelas, P., Woodhead, L., Seel, B., Szerszynski, B., \& Trusting, K. (2005). The spiritual Revolution: Why religion is giving way to spirituality. Oxford, UK: Blackwell.
Hervieu-Léger, D. (1999). La religion en movement: Le pèlerin et le converti. Paris, France: Flammarion. Religion on motion: the pilgrim and the convert.

Hidalgo, O. (2017). 'Rückkehr der Religionen' und 'Säkularisierung.' Über die Verwobenheit zweier scheinbar gegensätzlicher Narrative ['Return of religion' and 'secularization': On the interconnectedness of two seemingly opposite narratives]. In H. Zapf, O. Hidalgo, \& P. W. Hildmann (Eds.), Das Narrativ von der Wiederkehr der Religion, Politik und Religion (pp. 13-33). Wiesbaden, Germany: Springer.

Hood, R. W., Jr. (1975). The construction and preliminary validation of a measure of reported mystical experience. Journal for the Scientific Study of Religion, 14, 29-41. http://dx.doi.org/10.2307/1384454

Hood, R. W., Jr., Ghorbani, N., Watson, P. J., Ghramaleki, A. F., Bing, M. N., Davison, H. K., . . Williamson, W. P. (2001). Dimensions of the Mysticism Scale: Confirming the three-factor structure in the United States and Iran. Journal for the Scientific Study of Religion, 40, 691-705. http://dx.doi.org/10.1111/0021-8294.00085

Hout, M., \& Fischer, C. S. (2002). Why more Americans have no religious preference: Politics and generations. American Sociological Review, 67, 165-190. http://dx.doi.org/10.2307/3088891

Houtman, D., \& Aupers, S. (2007). The spiritual turn and the decline of tradition: The spread of post-Christian spirituality in 14 Western countries, 1981-2000. Journal for the Scientific Study of Religion, 46, 305320. http://dx.doi.org/10.1111/j.1468-5906.2007.00360.x

Hunsberger, B., \& Altemeyer, B. (2006). Atheists: A groundbreaking study of America's nonbelievers. Amherst, NY: Prometheus Books.

Joas, H. (2005). Braucht der Mensch Religion? Über Erfahrungen der Selbsttranszendenz [Does man need religion? On experiences of selftranscendence]. Freiburg, Germany: i. Br. Herder.

Keller, B., Coleman, T. J., \& Silver, C. F. (2016). Narrative reconstruction and content analysis in the interpretation of "spiritual" biographical trajectories for case studies. In H. Streib \& R. W. Hood (Eds.), Semantics and psychology of spirituality: A cross-cultural analysis (pp. 251274). Cham, Switzerland: Springer. http://dx.doi.org/10.1007/978-3319-21245-6_16

Keller, B., Streib, H., \& Hood, R. W. (2016). Redrawing the map: Varieties of "spiritual," "religious," and "secular" lives. In H. Streib \& R. W. Hood (Eds.), Semantics and psychology of spirituality: A cross-cultural analysis (pp. 373-382). Cham, Switzerland: Springer.

Keller, B., Streib, H., Silver, C. F., Klein, C., \& Hood, R. W., Jr. (2016). Design, methods, and sample characteristics of the Bielefeld-based cross-cultural study of "spirituality". In H. Streib \& R. W. Hood (Eds.), Semantics and psychology of spirituality: A cross-cultural analysis (pp. 39-52). Cham, Switzerland: Springer.

Klein, C., Keller, B., \& Traunmüller, R. (2017). Sind Frauen tatsächlich grundsätzlich religiöser als Männer? Internationale und interreligiöse Analysen zur vergleichenden Testung verschiedener Theorien [Are women really inherently more religious than men? International and interreligious comparisons of several theories]. In K. Sammet, F. Benthaus-Apel, \& C. Gärtner (Eds.), Religion und Geschlechterordnungen (pp. 99-131). Wiesbaden, Germany: Springer VS. http://dx.doi.org/ 10.1007/978-3-658-17391-3_5

Klein, C., \& Streib, H. (2015). Atheism as topic of the scientific study of religion and the profile of spiritual atheists. Paper presented at the International Congress on Science and/or Religion: A 21st Century Debate, Sigmund Freud University Vienna, August 29th.

Koschorke, A. (2013). "Säkularisierung" und "Wiederkehr der Religion"-zu zwei Narrativen der europäischen Moderne ["Secularization" and "return of religion"- Two narratives of European modernity]. In U. Willems, D. Pollack, H. Basu, T. Gutmann, \& U. Spohn (Eds.), Moderne und Religion: Kontroversen um Modernität und Säkularisierung (pp. 237-260). Bielefeld, Germany: Transcript. http://dx.doi.org/10.14361/ transcript.9783839419663.237 
Labov, W., \& Waletzky, J. (1967). Narrative analysis. In J. Helm (Ed.), Essays on the verbal and visual arts (pp. 12-44). Seattle, WA: University of Washington Press.

Martin, D. (2005). On secularization. Towards a revised general theory. Aldershot: Routledge.

McAdams, D. P., \& de St. Aubin, E. (1992). A theory of generativity and its assessment through self-report, behavioral acts, and narrative themes in autobiography. Journal of Personality and Social Psychology, 62, 1003-1015. http://dx.doi.org/10.1037/0022-3514.62.6.1003

McAdams, D. P., Diamond, A., de St. Aubin, E., \& Mansfield, E. (1997). Stories of commitment: The psychosocial construction of generative lives. Journal of Personality and Social Psychology, 72, 678-694. http://dx.doi.org/10.1037/0022-3514.72.3.678

McAdams, D. P., Hart, H. M., \& Maruna, A. S. (1998). The anatomy of generativity. In D. P. McAdams \& E. de St. Aubin (Eds.), Generativity and adult development: How and why we care for the next generation (pp. 7-43). Washington, DC: American Psychological Association. http://dx.doi.org/10.1037/10288-001

McAdams, D. P., St. Aubin, E. D., \& Logan, R. L. (1993). Generativity among young, midlife, and older adults. Psychology and Aging, 8, 221-230. http://dx.doi.org/10.1037/0882-7974.8.2.221

McCrae, R. R., Costa, P. T., Jr., del Pilar, G. H., Rolland, J. P., \& Parker, W. D. (1998). Cross-cultural assessment of the five-factor model-The revised NEO personality inventory. Journal of Cross-Cultural Psychology, 29, 171-188. http://dx.doi.org/10.1177/0022022198291009

Metzinger, T. (2013). Spiritualität und intellektuelle Redlichkeit. Ein Versuch [Spirituality and intellectual honesty: An essay]. Mainz, Germany: Selbstverlag. (for an English language introduction see http://www .philosophie.uni-mainz.de/metzinger/Metzinger_Berlin_2010_English .pdf)

Pew Research Center. (2015). America's changing religious landscape. Washington, DC: Author.

Pickel, G. (2013). Religion monitor-Understanding common ground. Gütersloh, Germany: Bertelsmann Foundation.

Pollack, D. (2003). Säkularisierung_Ein moderner Mythos? [Secularization-A modern myth?]. Tübingen, Germany: Mohr.

Ryff, C. D. (1989). Happiness is everything, or is it? Explorations on the meaning of psychological well-being. Journal of Personality and Social Psychology, 57, 1069-1081. http://dx.doi.org/10.1037/0022-3514.57.6 .1069

Ryff, C. D., \& Singer, B. H. (1998). The contours of positive human health. Psychological Inquiry, 9, 1-28. http://dx.doi.org/10.1207/s15327965 pli0901_1

Schnell, T. (2015). Dimensions of Secularity (DoS): An open inventory to measure facets of secular identities. The International Journal for the Psychology of Religion, 25, 272-292. http://dx.doi.org/10.1080/ 10508619.2014.967541

Schwarz, N. (1999). Self reports. How the questions shape the answers. American Psychologist, 54, 93-105. http://dx.doi.org/10.1037/0003066X.54.2.93
Sherkat, D. E. (2008). Beyond belief: Atheism, agnosticism, and theistic certainty in the United States. Sociological Spectrum, 28, 438-459. http://dx.doi.org/10.1080/02732170802205932

Silver, C. F., Coleman, T. J., III, Hood, R. W., Jr., \& Holcombe, J. M (2014). The six types of nonbelief: A qualitative and quantitative study of type and narrative. Mental Health, Religion \& Culture, 17, 990-1001. http://dx.doi.org/10.1080/13674676.2014.987743

Smith, J. M. (2017). Can the secular be the object of belief and belonging? The Sunday assembly. Qualitative Sociology, 40, 83-109. http://dx.doi .org/10.1007/s11133-016-9350-7

Stark, R. (1999). Secularization, RIP. Sociology of Religion, 60, 249-273. http://dx.doi.org/10.2307/3711936

Stolz, J. (2017). Institutional, alternative, distanced, and secular. Four types of (un)belief and their Gods. Nordic Journal of Religion and Society, 30 4-23. http://dx.doi.org/10.18261/issn.1890-7008-2017-01-01

Streib, H., \& Hood, R. W., Jr. (2016a). Coordinates for mapping "spirituality." In H. Streib \& R. W. Hood (Eds.), Semantics and psychology of spirituality: A cross-cultural analysis (pp. 219-238). Cham, Switzerland: Springer.

Streib, H., \& Hood, R. W., Jr. (2016b). Understanding "Spirituality"Conceptual considerations. In H. Streib \& R. W. Hood (Eds.), Semantics and psychology of spirituality: A cross-cultural analysis (pp. 3-18). Cham, Switzerland: Springer.

Streib, H., \& Klein, C. (2013). Atheists, agnostics, and apostates. In K. I. Pargament, J. J. Exline, \& J. W. Jones (Eds.), APA handbook of psychology, religion and spirituality (Vol. 1, pp. 713-728). Washington, DC: American Psychological Association.

Streib, H., Klein, C., \& Hood, R. W. (2016). Investigating "spirituality": Between survey data and the study of biographies. In H. Streib \& R. W Hood (Eds.), Semantics and psychology of spirituality: A cross-cultural analysis (pp. 27-38). Cham, Switzerland: Springer.

Streib, H., Wollert, M., \& Keller, B. (2016). The Faith Development Interview: Methodological considerations. In H. Streib \& R. W. Hood (Eds.), Semantics and psychology of spirituality: A cross-cultural analysis (239-250). Cham, Switzerland: Springer.

Trzebiatowska, M., \& Bruce, S. (2012). Why are women more religious than men? Oxford, UK: Oxford University Press. http://dx.doi.org/10 .1093/acprof:oso/9780199608102.001.0001

Voas, D. W., \& Chaves, M. (2016). Is the United States a counterexample to the secularization thesis? American Journal of Sociology, 121, 15171556. http://dx.doi.org/10.1086/684202

Weber, M. (1994). Briefe 1909-1910. Max Weber Gesamtausgabe [Letters 1909-1910: Max Weber complete edition] Part II (Vol. 6). Tübingen, Germany: Mohr Siebeck.

Zuckerman, P., Galen, L. W., \& Pasquale, F. L. (2016). The nonreligious. Understanding secular people and societies. Oxford, NY: Oxford University Press. http://dx.doi.org/10.1093/acprof:oso/9780199924950.001 .0001

Received April 27, 2018

Accepted May 2, 2018 